\title{
Gene drive and RNAi technologies: a bio-cultural review of next-generation tools for pest wasp management in New Zealand
}

Symon Palmer, Peter K. Dearden, Ocean R. Mercier, Alan King-Hunt \& Phillip J. Lester

To cite this article: Symon Palmer, Peter K. Dearden, Ocean R. Mercier, Alan King-Hunt \& Phillip J. Lester (2021): Gene drive and RNAi technologies: a bio-cultural review of next-generation tools for pest wasp management in New Zealand, Journal of the Royal Society of New Zealand, DOI: 10.1080/03036758.2021.1985531

To link to this article: https://doi.org/10.1080/03036758.2021.1985531

View supplementary material $₫$

\section{Published online: 14 Oct 2021.}

Submit your article to this journal 지

\section{山 Article views: 5}

Q View related articles 


\title{
Gene drive and RNAi technologies: a bio-cultural review of next-generation tools for pest wasp management in New Zealand
}

\author{
Symon Palmer (iD) ${ }^{a}$, Peter K. Dearden $\mathbb{D}^{\mathrm{b}}$, Ocean R. Mercier $\mathbb{( D D}^{\mathrm{a}}$, \\ Alan King-Hunt ${ }^{a}$ and Phillip J. Lester $\mathbb{B}^{c}$ \\ ${ }^{a}$ Te Kawa a Māui - School of Māori Studies, Te Herenga Waka - Victoria University of Wellington, Wellington, \\ New Zealand; ${ }^{\mathrm{b}}$ Genomics Aotearoa, Bioprotection Research Centre, and Biochemistry Department, \\ University of Otago, Dunedin, New Zealand; ' $S$ chool of Biology, Te Herenga Waka - Victoria University of \\ Wellington, Wellington, New Zealand
}

\begin{abstract}
There is a global need for novel, next-generation technologies and techniques to manage pest species. We review work on potential step-changing technologies for large landscape (>1000 hectares) pest management of social Vespula wasps. We also review Māori perspectives on these controls to gauge social and cultural acceptability to research, test and use of novel controls. Approaches discussed are the use of gene silencing (RNAi) and gene drives (CRISPR-Cas 9) involving genetic modification, which has potential for pest control but vary in feasibility, cost, benefits and off-target risks. RNAi may be better suited for wasp control in high-value cropping systems due to scaling inefficiencies. Gene drives offer potential for large-scale control but would require legislative and wide social deliberation due to their status as genetic modification. Both RNAi and gene drives will require consultation with tangata whenua. Māori interest groups agreed that exotic wasps must be controlled and expressed aversion to non-targeted traditional control methods. We present a diversity of opinions in parallel with scientific research underscoring the need for continued dialogue with Māori. Novel biotechnological controls must satisfy a broad range of social and cultural criteria, receive regulatory approval, along with being demonstrated as safe, selective, and cost-effective.
\end{abstract}

\section{ARTICLE HISTORY}

Received 7 January 2021

Accepted 22 September

2021

\section{KEYWORDS}

Conservation; pest management; gene drives; RNAi; Māori; Indigenous engagement; CRISPR

\section{Introduction}

The efficient, socially acceptable and environmentally safe control of pest species that threaten biodiversity is an ongoing and difficult challenge. Approaches for pest control have historically been based on the use of synthetic pesticides, biological control via the introduction of predators or parasites, or the use of artificial pheromones to interrupt mating or trap individuals. The off-target effects of both broad-spectrum pesticides and biological control agents have highlighted that there is an increasing need for the 
discovery of new and highly targeted technologies, although these may involve controversial techniques that require public discourse based on multiple (not just Western scientific) perspectives for acceptance. Synthetic pesticides, in particular, have issues in escalating costs of development and registration, resistance development, as well as increasing public demand for sustainability and humane animal control (Goldson et al. 2015). Pests that are widespread over large areas of native vegetation or conservation land also represent an additional problem because biodiversity managers are typically unable to apply pesticides at landscape scale. New Zealand's Biological Heritage programme under the National Science Challenge has recognised this need with a specific goal to develop new, cost-effective technologies to sustainably control pests and allow biological heritage - which also encompasses Māori (the Indigenous people of New Zealand) and Pākehā (non-Māori) cultural heritage - to flourish across all landscapes (Norton et al. 2016). This research supports the government's ambitious Predator Free 2050 programme, which aims to eradicate invasive species from Aotearoa New Zealand with precision. Mustelids (Mustela spp.), Brushtail Possums (Trichosurus vulpecula), and rats (Rattus spp.) are one area of research with a variety of techniques for control under consideration, including advanced trapping technology and speciesspecific toxins (Murphy et al. 2019). Exotic wasps, specifically, the German wasp (Vespula germanica L.) and common wasp (Vespula vulgaris L.) are another detrimental pests to biodiversity, impacting the unique native ecosystems in Aotearoa, New Zealand. These play a key role in the ecosystem, feeding other native species like birds and reptiles that are taonga (treasured) species to Māori. Wasp densities are likely to negatively impact native invertebrate populations due to predation, causing reduced food sources for native birds (Burne et al. 2015; Lester and Beggs 2019). Native invertebrates evolved without competition from mammals due to the isolation of Aotearoa New Zealand and endemic biota (McGlone et al. 2010; Belcher 2021), which in turn allowed flora to flourish and become distinctive (Antonelli et al. 2011).

Invasive social wasps threaten taonga and human health; thus, they represent an excellent case study for pest management. The wasps are native to Eurasia, but over the last century, have invaded Australia, South America, Hawaii and Aotearoa New Zealand (Lester and Beggs 2019). Vespula wasps are generalist predators that consume between 0.8 and 4.8 million prey items per hectare (Harris 1991). Wasps are estimated to cost $\sim$ NZ\$133 million annually and cause human mortality (MacIntyre and Hellstrom 2015). Vespula wasps have spread throughout Aotearoa New Zealand and occupy extremely high densities of up to 40 nests per hectare (Lester et al. 2017). The highest densities are observed in over a million hectares of native honeydew beech forest (Lester and Beggs 2019). Their control in these systems is recognised as a critical issue for entomology in Aotearoa New Zealand (Lester et al. 2014). Wasp control using insecticides like fipronil (Vespex ${ }^{\oplus}$ ) can be effective (Edwards et al. 2017); however, such insecticides are unlikely to be used over widespread areas comprising of hundreds of thousands or millions of hectares due to the manual labour required to administer bait stations in remote areas. Many other pest species share similar characteristics with social wasps: they are widespread over large areas, often present in economic and conservation areas, and are ecologically and environmentally damaging. There is a clear need to develop highly targeted, environmentally safe, and socially and culturally appropriate approaches for the control of wasps, providing a roadmap for other pests. 
The negative impact on taonga species caused by invasive predators is a critical issue for Māori. The Māori worldview is intricately relational, requiring a holistic environmental approach; taonga are one aspect of the wider connections to Te Ao Māori (the Māori world), which are culturally embedded through whakataukī (proverbs) and whakapapa (genealogy), making them critical to cultural wellbeing. Benton et al. (2013) describe taonga as 'a socially or culturally valuable object, resource, technique, phenomenon or idea'. Examples of taonga include Indigenous timbers, kūmara, pōhutukawa, and kererū (Waitangi Tribunal 2011). The definition highlights the tangible and intangible nature of taonga, which may differ from a Western worldview that often relies on the physical and measurable. Māori connection to land is unique in that whakapapa (genealogy) can be represented in multiple physical landscapes like maunga (mountains) and awa (waterways), which hold iwi narratives and function as personal identifiers. Cosmogenic ancestors like Tāne Māhuta (god of the forests) are still acknowledged today in tikanga (protocols) such as karakia (incantations) and whakapapa to native species. Also relevant to the protection of taonga species are kaitiaki (guardians), traditional stewards of the environment acting in the interest of hapū (local tribes), and rangatiratanga (self-determination), the ability to make decisions that encompassed cultural values and identity.

In Te Ao Māori (the Māori worldview), ngārara (insects and reptiles) are culturally symbolic, embodying whakapapa that connects to Atua (deities) like Tāne-mahuta (deity of forests and birds) (Sissons 2019), sometimes acting as tohu (signs), indicators of environmental wellbeing (Baker 2012). Some iwi have strong connections to native invertebrates, including katipō spiders (Latrodectus katipo) and the grasshopper-like cave wētā (Rhaphidophoridae). Invasive predators are thus critical to Māori as they threaten taonga species that inform a foundational aspect to cultural practices and identity. Collier-Robinson et al. (2019) explained that genomic data extracted from taonga species is also taonga and must be treated accordingly. Framing genomic data from native species as taonga also opens considerations to how non-native species might be studied. Taonga are guaranteed to Māori in Article 2 of the Treaty of Waitangi/Te Tiriti o Waitangi, an agreement signed between Mãori and the British government in 1840. ${ }^{1}$ This bicultural relationship cannot be overlooked when considering the conservation of taonga species in Aotearoa New Zealand. Similarly, the conservation of taonga species relies on the control of invasive predators.

In this paper, we present a review of research concerning the feasibility and technical progress on both RNAi and gene drives, and the current perceptions of these technologies among a variety of Māori voices. RNAi is the disruption of RNA by silencing protein synthesis that would otherwise produce a trait, e.g. the formation of the cuticle or exoskeleton. Gene drives involve the insertion or deletion of genetic information that is almost guaranteed to be inherited and cause demographic shifts in the population, such as the production of only male offspring, leading to population decline. Based on a survey of stakeholders (including agricultural businesses, scientists, and Māori organisations), these technologies form the basis for research on possible landscape control techniques of pest wasps. A focus on tangata whenua views aligns with Te Kāhui Māori, the Māori advisory group to the National Science Challenge, and a Vision Mātauranga emphasis on inclusion of Māori voices and diverse perspectives in the discussion and addresses an identified demographic gap (Russell 2014). We set the scene for emerging 
technologies by reviewing the ethical and technical context of novel pest tools in Aotearoa New Zealand. We review the current research status of RNAi and gene drives in concert with the ethical context by weaving participant quotes that speak to social concerns that connect with the technical science. These early conversations with tangata whenua demonstrate the socio-cultural complexities in the genomics space and draw attention to our unique political context that is founded upon Te Tiriti o Waitangi.

\section{Ethical considerations}

The challenges in ethically developing and governing emerging technologies like gene drives are recognised globally. In North America, George et al. (2019) argue for the utilisation of 'free prior and informed' consent for synthetic biology ethical discussions. An approach suggested by Australian academic Dryzek et al. (2020) is to host a global citizen forum where participants representing a wide aspect of society attend a forum where they engage with the technical, ethical and social aspects associated with these genetic editing technologies. Garrison et al. (2020) applies 'dynamic consent' to genomic research, allowing the ongoing revision of consent to genetic research. Locally, discourse regarding novel biotechnologies and ethics references a social licence to operate (SLO) (Edwards et al. 2019; Kirk et al. 2019; Dearden et al. 2018; Mercier et al. 2019). SLO began in controversial industries such as mining (Moffat and Zhang 2014), making it a convenient starting point to mirror dialogue on potentially contentious topics like biotechnologies. Ogilvie et al. (2019) demonstrate how SLO can facilitate conversation on complex issues like unmanned aerial vehicles in biosecurity by adapting the concept to an activity used in interviews called an 'SLO spectrum'. However, consent and SLO mechanisms must be applied in ways that are consistent with Treaty principles (Ruckstuhl et al. 2014) and enhance rangatiratanga (self-determination) (Palmer et al. 2020).

While parts of the science community describe CRISPR-Cas 9 (cluster regularly interspaced short palindromic repeats), commonly referred to as gene drives, as a revolutionary change to accessibility in genomic research due to its cost-effectiveness to edit genetic information, Montenegro De Wit (2020) draws attention to the equity issues such technologies may pose if representation and justice does not feature alongside these advancements. The call to centre Indigenous peoples' concerns in the development of gene drives is of global interest to ensure that inequities in science, healthcare and so on are not reproduced in this next frontier of science (Tsosie et al. 2020; Fox 2020; Taitingfong 2019).

Gene drives and RNAi technologies make for recent additions to the suite of genetic pest control approaches that have raised concerns for Māori. Almost 20 years ago, the Royal Commission on Genetic Modification (2001) captured early deliberations on these issues, acknowledging Te Tiriti o Waitangi and the cultural concerns of Māori, although recommending a cautious green light to genetic modification (GM). The Commission was critiqued for its selective prioritisation of invested parties (Campbell 2004) and the polite disregard of Māori opposition (Hutchings and Reynolds 2004). At the time, GM was surrounded by negative public perceptions, represented by the majority of submissions made; however, the overarching result leant towards an openness to GM (Rogers-Hayden and Hindmarsh 2002). Māori perspectives have since been documented in a variety of qualitative research topics pertaining to biotechnologies, including 
biobanking (Taupo 2012; Hudson et al. 2016) and opposition to GM applications in animals (Satterfield and Roberts 2008; Smith 2006). Cultural concerns for Māori in genetic research often cite harm to whakapapa (genealogy), mauri (life-fore), tapu (sacredness), and kaitiakitanga (stewardship) (Hudson et al. 2019). These concepts often overlap and cannot be separated as they form the foundation for the Mãori worldview. Supplementing these qualitative studies is a recent quantitative survey of general public $(n=8199)$ perceptions that found a preference for pest-specific toxins $(52 \%)$ and restrained support for gene drives (32\%) (MacDonald et al. 2020).

The potential of gene drive technologies reignites the Royal Commission debate, where there has been little government progress since its recommendations. Te Apārangi The Royal Society of New Zealand argue that the current Hazardous Substances and New Organisms Act 1996 (HSNO 1996) legislation is outdated and ill-equipped, drawing attention to the legislative 'grey areas' that currently only regulate in vivo modifications (resulting from procedures conducted internally to a living organism) and ignore in vitro (resulting from procedures conducted external to a living organism) (Royal Society 2019). Everett-Hincks and Henaghan (2019) advocate for a new policy that is guided by Treaty principles and the Waitangi Tribunal claim report, Ko Aotearoa Tènei (WAI262) recommendations. WAI262 also critiqued legislation regarding GM for not supporting Māori interests as kaitiaki or protecting mātauranga from bioprospecting (Waitangi Tribunal 2011). Bioprospecting is the scoping of biological resources with the intent of commodifying and remains a significant concern for Indigenous cultures globally (Ratuva 2009; Takeshita 2001). Protecting taonga species is recognised in Aotearoa New Zealand; however, genomic sequencing is of interest globally, raising countless ethical concerns. For example, native bird specimens also exist internationally with no regulation or requirement to engage with tangata whenua (Inwood et al. 2020). Reviewing conservation policy in Aotearoa New Zealand will also present opportunities to enhance recognition for Māori concerns, particularly biodiversity loss, which currently lacks support for iwi and hapū to manage land as kaitiaki (Ruru et al. 2017). International appetite to centre marginalised groups in genetic editing (Feliú-Mójer 2020), coinciding with the potential applications of such technology, historical context, and inadequate legislation, strengthens the rationale to lead these complex conversations with a Tiriti focus.

In order to protect taonga species and production industries at a landscape scale, there is a need to develop novel tools and strategies to control invertebrate pests, but it is critical that these tools are socially acceptable. Some new pest controls involves historically controversial technologies such as GM. Strategies to negotiate these issues must account for various societal groups and their interests (Kirk et al. 2019). Discussion should be grounded in recognition of Aotearoa New Zealand's Treaty partnership, ensuring Māori perspectives guide decision-making. Thus, identifying 'socially acceptable' controls requires a conversation that is informed by up-to-the minute science, recognition of how ethical, cultural, spiritual and social considerations have informed previous debates, rigorous examination of the technologies from all angles to fully assess risks alongside opportunities, and openness from all sides. Here, we present a review of recent groundwork regarding two potential tools for pest wasp management: RNAi and gene drives. Complementing this research are tangata whenua views gathered from three parallel mixed-method qualitative studies that aim to gauge perspectives on 
these issues. While acknowledging these studies are reported in detail elsewhere (Mercier et al. 2019; Palmer 2019; King-Hunt 2019), including research on gene drive development and gene silencing (Inwood et al. 2020; McLaughlin G and Dearden 2019), it is our aim here to weave qualitative interview data with an assessment of RNAi and gene drive technologies to provide an innovative review that links the biological sciences and the social, mātauranga and tikanga Māori.

\section{Feasibility and society}

In this section we present an analysis of both RNAi and gene drive technologies in the potential application to control pest wasps in Aotearoa New Zealand. The logistical aspects of each technology are described, and participant quotes are presented as responses to novel aspects and technical challenges, along with additional socio-cultural analysis. Participants were Māori students who had critically engaged with biotechnologies through assignments at university $(n=13)$ (see Mercier et al. 2019), Māori business owners who may benefit economically from pest wasp control $(n=10$, across eight businesses) (see Palmer and Mercier 2020), and religious and spiritually affiliated Māori $(n=16)$ (see King-Hunt 2019). Reference to each study that quotes are taken from are codified in this paper as: S1 (Māori students); S2 (Māori businesses), S3 (religious or spiritually affiliated). Each study has distinctive coding attributed to participants. These are retained in this article to ensure the mana (prestige) attached to the knowledge shared by interviewees is recognised and upheld. These quotes offer a snapshot of key concerns from tangata whenua for consideration in the further development of these biotechnologies.

While the social perspectives used in this paper are reported elsewhere in detail (see Mercier et al. 2019; Palmer and Mercier 2020; and King-Hunt 2019), for context, an overall impression of pest control from these studies is briefly described here. In all three social perspective studies, the majority of participants disagree with 'doing nothing' about pests and hold low levels of support for poisons with concern for offtarget impacts. This means they are willing to consider and engage with possible new technologies. Other issues raised related to safety and risks; such as off-target effects, unintended consequences, and impacts on whakapapa and mauri. Participants also mistrust the economic and socio-political systems within which these decisions are made.

\section{RNA interference (RNAi)}

RNA interference, or RNAi, has been proposed as a potential pest control method since 2005 (Huvenne and Smagghe 2010). The technique involves the synthesis and delivery of double-stranded RNA (dsRNA) to pest species, typically by feeding. This dsRNA targets highly specific messenger-RNA (mRNA) of the pest species. It triggers an endogenous pathway that causes the pest mRNA to be degraded and targeted genes to be silenced (Zamore 2001). This approach is attractive as it provides a highly specific insecticide that could be used widely in the environment, with no off-target effects. In Aotearoa New Zealand, RNAi technologies are not regarded as GM (as it will not produce a permanent change in genotype) and thus may be legislatively and socially easier to implement than a solution using GM. We note, however, concerns over these RNAi 
approaches by some researchers. Heinemann (2019), for example, critiqued the Environmental Protection Authority's (EPA) position on RNAi in Aotearoa New Zealand. He considered that the EPA failed to accurately review the potential for exo-dsRNA inheritance. Heinemann made the case that in some situations there may be evidence that dsRNA could change DNA, which would include by methods of heritable methylation of nucleotides. How common and likely any such changes are in real life is unknown, but we cannot rule them out as a possibility.

While legislation may differentiate this technology from GM, our participants were not so convinced. In statements like 'I'm looking here at RNAi and gene drive, and would you say they're quite similar things?' (NR S3 ${ }^{\star^{2}}$ ). Across studies, both technologies were at times indistinguishable to participants and appeared to produce the same result, pointing to the complexity of communicating scientific principles to a broad audience.

RNAi has already been used effectively in insect suppression or control, targeting flies (Powell et al. 2017), beetles (Palli 2014), aphids (Tariq et al. 2019), moths (Whyard et al. 2009; Lim et al. 2016), cockroaches (Revuelta et al. 2009). Interestingly, RNAi technologies for pest control have not been widely developed in Hymenoptera, though the use of RNAi in other research applications is common for this order ( $\mathrm{Lu}$ et al. 2009; Weiner et al. 2018). A sub-group of our team, based at the University of Otago are currently developing RNAi techniques in Vespula wasps (McLaughlin, Gilligan and Dearden, unpublished data).

Concerns about biotechnologies in pest management have been raised by lay participants, but how do these compare with development concerns in the laboratory? Themes from interviews in the three studies included concern for off-target effects, the need for more information before feeling confident in decision-making, and the implications for tikanga Māori. In contrast, the three key challenges for the use of RNAi as a control method for pests such as wasps are targets, delivery and efficacy.

The nucleotide sequence targeted in the pest species with RNAi must be selected carefully after a thorough examination of the genome. Draft genomes of three pest vespoid wasps have been sequenced and have provided this information (Harrop et al. 2020). Sequences chosen as targets should be specific to a gene or genes essential for wasps' survival and needs to be monitored for off-target effects on other species. The optimal concentration of the dsRNA should be determined to induce optimal silencing of the gene selected. This can be limiting for methods of delivery such as feeding and/or injection; thus these methods need to be examined carefully and may differ in efficacy between species and gene targets. As wasps are holometabolous insects, the life stages receptive to feeding should be tested for RNAi effects; while adult life stages can be more efficient for handling, the younger stages tend to show greater silencing effects (Huvenne and Smagghe 2010).

For RNAi to be used for social wasp control, it would need to be delivered in an efficient way that can be spread over broad and rough terrain. It seems likely that the only feasible way to do this would be through an oral route using wasp baits. Concerns have been raised on the stability of dsRNA applications or in baits. In other systems, dsRNA has been shown to be stable, continuing to be active in some cropping systems for up to 28 days after application (San Miguel and Scott 2016). Another study has shown that dsRNA can be stabilised and preserved, allowing pest-suppression activity against plant pathogens for 20 days and the presence of dsRNA for at least 30 days 
(Mitter et al. 2017). However, the need for an oral delivery route and sustained environmental stability of RNAi requires tailored formulation of the RNA molecules. Adult wasps bring protein sources to the nest for larvae, which reciprocate with trophallaxis feeding (Spradbery 1973). Therefore, RNAi delivered to larvae as a food source could kill larvae and adults alike, with initial delivery killing larvae, and any trophallaxis occurring by infected larvae killing adults. Even if RNAi feedings only killed larvae, this would prevent the production of queens at the end of a nest cycle. However, RNAi via feeding can fail for many reasons such as a low concentration of the dsRNA reaching the gut epithelium; which would need to be addressed in containment experiments to establish an effective dosage. Field trials would be necessary, and it should be noted that RNAi approaches show more variation in efficacy in the field than in the laboratory (San Miguel and Scott 2016). These inconsistencies speak to another concern raised during interviews; the inability to accurately predict outcomes or side-effects: 'the technologies and the effects. And the effects today, and the effects in fifty years, a hundred years. You can't know all of that' $\left(2 \mathrm{~T}, \mathrm{~S} 1^{\star}\right)$.

The cost of RNAi as a control method would likely be substantial, limiting its use in a pesticide formulation for highly widespread species such as wasps in conservation areas. Only a few years ago, a gram of RNA cost circa \$1000 USD; recently it has cost closer to $\$ 1$ (Shaffer 2020). However, the research and development before a viable product is available would be significantly more as would the delivery and regulatory consultation process. Trials with dsRNA to control parasitic Varroa mites in honeybee colonies are being conducted at the scale of many thousands of hives over several states in the United States, towards the development of a commercialised product (Masucci 2020). Some participants were sceptical of the cost associated with novel biotechnologies and pest management. One participant evaluated the financial investment of genetic tools in pest management, asking if it could be better spent to have a secure and direct impact on the environment:

If you say we should spend ... half a billion dollars to wipe out pests [...] you could say instead frame the question ... should we spend half a billion dollars on tidying up the waterways? (1T; S1 cited in Palmer et al. 2020:G)

Another issue is that RNA will degrade over time, rendering it useless if applied over large areas unless consumed immediately or unless it is preserved, for example, by encapsulation. By contrast, participants appreciated the permanence of gene drives: 'if I'm thinking pest-free then I went to the gene drive end as the most agreeable ...' (4C; S1 cited in Mercier et al. 2019, p. 150). The use of RNAi via transgenic plants could overcome these issues and has proven successful for the control of other invasive insects (Mao et al. 2007; San Miguel and Scott 2016; Majidiani et al. 2019). Transgenic plants would, however, not be as feasible an option for common and German wasps under current legislation in Aotearoa New Zealand.

Ultimately, RNAi holds promise as a specific, genetic technique to control pest populations, but probably not for wasp populations in native forests at the scale of many hundreds of thousands of hectares. RNAi could be employed as an effective method capable of reducing wasp densities in smaller areas or for high-value commercial operations such as mānuka beekeeping, should promising target genes and delivery mechanisms be developed. 


\section{Gene drives}

Gene drives are based on a genetic modification of the pest. This approach requires the production of a targeted double-stranded break in DNA, most often caused by a CRISPR system. This will cut a target DNA sequence based on complementarity to a guide RNA (gRNA) homing segment, insert newly programmed DNA, and repair the DNA. The CRISPR generated mutation will then copy itself anywhere within a genome where there is a sequence complementary to the gRNA (McLaughlin G and Dearden 2019). This system converts individuals heterozygous for the mutation into homozygotes, effectively driving the target gene (even a gene lowering fitness) through populations over successive generations. Genetically modifying wasps species using the CRISPR approach has been achieved in jewel wasp Nasonia vitripennis, in which eye pigment was altered (Li et al. 2017). While a variety of modelling and laboratory studies have been performed, no field releases of gene drives have been undertaken anywhere, to date. Recognising the negative impact social wasps have on Aotearoa New Zealand's ecosystems and the potential for gene drive technologies to be a successful pest control technique makes for an ideal match if found admissible by the public (Dearden et al. 2018).

Considerable debate is ongoing regarding the use of gene drives in conservation. There is concern around their efficacy, resistance development, potential for global spread of genetically modified species and species extinctions, and other issues (Raghu 2015; Esvelt and Gemmell 2017; Zentner and Wade 2017; Moro et al. 2018; Noble et al. 2018). These concerns were noted by participants in all three social perspective studies, in statements like '.. the gene drive might interfere with something else that's native here' $\left(4 \mathrm{C}, \mathrm{S}^{*}\right)$. Such concerns extended beyond Aotearoa New Zealand, considering the potential impact on ecosystems overseas. 'You kind of worry about whether or not it's going to get out of the country, because it's native somewhere else, but the benefits outweigh all of that' (4C; S1 cited in Mercier et al. 2019, p. 151).

Benefits and risk were frequently weighed-up and discussed by participants throughout interviews. 'I'm not saying do it now. I'm saying, I like the sound of investigating [gene drive] further ... it may be less harmful than these ones which we know have environmental consequences and affect other species' (BE, S3 cited in King-Hunt 2019, p. 81). However, an overriding theme was the concern for information and communication on these techniques. Interestingly, this concern also emerged in the most informed cohort, S1: 'It's very jargony. Especially the RNA interference' $\left(\mathrm{S}^{\star}\right)$. This cohort also raised concern for how to communicate these technologies to a broad audience. In S2 the primer was seldom read pointing towards a need to consider other science communication media (Palmer and Mercier 2020). The scientific complexity of these technologies for lay audiences surfaced in comments like: 'I don't really understand that one' (Pūkeko, S2*), and 'I see those things as being really similar' (NR, S3*). While a brief overview of each biotechnology was given in the primer and interview introduction, complex questions emerged during conversation that highlight the considerations being made by participants, which are multifaceted: 'Which one [biotechnology] is more intrusive?' (NR, $\mathrm{S}^{\star}$ ).

Work has been ongoing to further inform and understand the benefits, risks and opportunities represented by gene drives for invasive wasp management. Lester et al. (2020) investigated a potential gene drive using eight different spermatogenesis targets 
in the invasive common wasp. Reducing spermatogenesis would cause partial or total infertility in male wasps. The eight different spermatogenesis genes showed varying levels of variation in the introduced and native range. Some genes displayed no variation in the invaded range of Aotearoa New Zealand, while other genes sequences were more variable. This variation informs us about potential resistance development to gene drives, indicating that some genes would be more susceptible to resistance development than others. This knowledge could also be used to enable a 'precision drive' (Esvelt et al. 2014), targeting genotypes present in Aotearoa New Zealand but not all common wasp genotypes in the home range of Eurasia. In vitro CRISPR-Cas9 testing showed guide-RNA target specificity and efficacy for spermatogenesis genes within common wasps, but no cross-reactivity in bees or related wasp species. Mathematical simulation modelling demonstrated a trade-off between impact and infiltration of a gene influencing spermatogenesis. A drive causing complete male sterility would not spread. Partial sterility, however, appeared more effective in limiting wasp population size. The greater the population suppression via increasing sterility, the longer it takes for the gene to spread through the population (Lester et al. 2020). Participants discussed fertility interference in a range of ways, including concerns about the technology being applied to humans and concerns about the wasp's right to procreate.

I think the gene drive ... it's sort of like direct tampering with whakapapa in a way ... We'd have to live with the consequences because that's our mokopuna essentially that they're talking about. Whereas in here it's like... if I was a wasp, I'd be offended, you know, you're telling me I can't have kids? (DA, S3King-Hunt 2019, p. 84)

A key benefit of gene drive technology would be that it could be self-perpetuating and therefore have a relatively cheap ongoing cost, acting in a similar fashion to biological control. Genetically modified wasps would be released, and the genes then spread. This technology could readily allow for wasp control at the scale of millions of hectares, covering all of Aotearoa New Zealand. However, depending on the type of gene drive implemented and how it affects populations, it may take some decades to see effects on pest populations (Lester et al. 2020). When considering the potential application of biotechnologies to their business, participants in S3 discussed concerns about using gene drives, including the 'potential harm something like this [gene drive] would have' in unforeseen risks (Mōhua cited in Palmer and Mercier 2020, p. 166), and an incline towards quicker killing methods (Palmer 2019, p. 63). Kirk et al. (2019) note the potential spread of genetically modified wasps back to their home range, the potential for hybridisation of genetically modified wasps with off-target species, and unintended consequences of the removal of these predators as key concerns. Considerable national and international discussion would be needed on the use of this technology prior to its potential implementation.

\section{Bridging themes}

In the 'post-truth' era where conspiracy theories regarding new technologies like 5G telecommunications and anti-vaccination groups proliferate, strategies to combat misinformation, create transparency, and foster trust on topics such as gene drives should also be considered alongside legislative change. Future research engaging with Māori views on complex issues like novel pest management tools may be well suited to forum style 
discussions in the shape of wānanga, a tikanga based deliberation process. Whare wānanga were traditionally places of highly skilled learning, a definition that stands today in the names of tertiary institutions (Mead 2003). To actively wānanga is to deliberate, discuss and learn. Wānanga as a platform for discussion with research participants is grounded in tikanga and local contexts to co-create and exchange knowledge (Mahuika and Mahuika 2020). Wānanga can work in tandem with Kaupapa Māori methods, mātauranga concepts and decolonisation pedagogy, contributing to shared knowledge and rangatiratanga (self-determination) (Smith et al. 2019).

Collectively, any technology that engages with genetics has socio-cultural ramifications that will be specific to culture, societies, and geopolitical boundaries. Our participants speak to these issues in a range of statements that highlight the complexity within the context of Aotearoa New Zealand; however, these ideas may offer touchstones for other countries with Indigenous populations when engaging in dialogue on these topics.

... the other issue I do see is that if some of the genetic techniques were introduced there's no way to respect different iwi preferences, like if some iwi or hapū are very much opposed to it ... (YP, S3)

Geographical boundaries are imposed on Indigenous cultures by colonisation. This is true in Aotearoa New Zealand where regional dialects and tikanga variations are witnessed; and also represented internationally, for instance, on Turtle Island (North America), where tribal boundaries transverse state lines and borders. The quote above asks what if certain groups are okay with a gene drive release and others are not? As an island nation, it may be possible to limit releases to only North or South Island, but what are the chances of the release being exposed to areas that will not permit it?

If it wasn't for our tikanga and wasn't for our iwi and our hapū, I mean, we wouldn't have got that 1080 drop done ... so that's empowering tikanga to look after our ngāhere [forests] (Kākāpō, S2 cited in Palmer and Mercier 2020, p. 168).

Tikanga is the original law of the land in Aotearoa New Zealand and emerged with the development of a 'Māori' tribal identity following East Polynesian migration in c1300, through to the settlement of Europeans in the early 1800s and the signing of the Treaty in 1840 (Mikaere 2005; Jones 2016). Tikanga can vary between iwi in different regions; however, many overarching similarities remain. It is important to note that mana or authority lies with the community where discussions take place. As demonstrated in the above quote, locally applied tikanga can create an appropriate process to assess 1080, a broad-spectrum poison that is frequently deemed controversial in Māori spheres and some rural communities (Green and Rohan 2012; Ogilvie 2010). The calls to acknowledge that Treaty principles (Everett-Hincks and Henaghan 2019) and rangatiratanga (Palmer et al. 2020) are valid considerations that will lead to equitable outcomes for Māori and enhance conservation efforts, benefiting all:

If we are venturing into genetically modifying animals we view as pests then how far of a leap really is it for people to then view certain races of humans as pests. (NR, S3 cited in King-Hunt 2019, p. 84) 
The fear of eugenics is not far removed from suppressing fertility in pests, in the views of some of the participants. For marginalised groups, this concern is compounded by the legacy impacts of colonisation, which are intertwined with Western science. The period of the Enlightenment sought new knowledge often at the expense of Indigenous peoples and their own native sciences (Medin and Bang 2014). These roots are still evident in contemporary scientific research (Smith 2012); however, a recent shift in Aotearoa New Zealand beyond one knowledge system sees the integration and recognition for the value of mātauranga, presenting new opportunities for collaboration and innovation. Mātauranga and Western science are active in biosecurity, conservation efforts, ecology, and government agencies. Generational advancements like gene drives must take care to prevent canonisation of knowledge and the disenfranchisement of Indigenous peoples once again.

Gene drives are seen as a step forward in germline editing possibilities. The International Commission on the Clinical Use of Human Germline Genome Editing (ICCUHGGE) recently published guidelines on the matter suggesting an 'incremental' use of genome editing but only in monogenic diseases that are debilitating or life-threatening (National Academy of Medicine et al. 2020). ICCUHGGE also encourages societal debate on these issues. While legislation reform will be required for new technologies to support conservation efforts and prepare Aotearoa New Zealand for readiness to police potential international releases, the ethical reach of such technologies must also be examined carefully. How can future legislation restore confidence to these concerns and protect society from unintended use or manipulation of these tools beyond pests. Additionally, what preventative or punitive measures can be put in place?

Whether it comes to agreeing with kind of RNA interference or gene drive and all of those kinds of things ... I think it's probably a good thing ... something like this [discussion] so we figure out where we stand on these things and how we move forward. $\left(3 \mathrm{~N}, \mathrm{S1}^{\star}\right)$

Both RNAi and gene drives have their unique drawbacks, be it technical science that requires future research and modelling or the socio-cultural issues highlighted by participants in studies so far. These technologies sit against a backdrop of socio-cultural and legislative questions that will need to be addressed before any potential development, testing and release in Aotearoa New Zealand. While recognising that a national dialogue is needed on these issues going forward (Palmer et al. 2020; MacDonald et al. 2020), such an exercise will require significant resourcing and planning. Our participants valued participating in an early conversation on biotechnologies. Within our research programme we look forward to making headway on some of the issues raised in the current social perspectives literature.

\section{Conclusion}

This paper has presented a review of the state of current research regarding the potential use of biotechnologies in pest wasp management. Exotic wasps threaten taonga species, making wasps a critical issue to both tangata whenua and entomology. Early discussions show a wide range of concerns regarding the risks of off-target effects and the distinguishing features between RNAi and gene drives. However, the need to address invasive species' negative impacts on flora and fauna are recognised by participants. A key 
requirement, or limitation, is that novel pest management tools need to be practical for potential use over large areas that include the $>1$ million hectares of native beech forests where pests such as social wasps reach the highest densities anywhere in the world (Lester and Beggs 2019). RNAi and gene drives each pose technical issues and require further investigation before considering field tests. RNAi may be of use for controlling wasps or other pests in high-value commercial settings. These highly-targeted approaches might be of substantial use for wasp control in situations such as mānuka honey production, where wasps can be a considerable problem (Lester and Beggs 2019). Gene drives have both benefits and costs. The benefits include being relatively cheap to design and implement, and modelling studies indicate they may be effective for pests such as wasps. Potential costs and risks include the lag time in seeing reduced pest numbers and issues associated with potential harm (Palmer 2019), such as the return of genetically modified individuals to their home range, potential hybridisation events, and unintended consequences of the removal of these predators (Kirk et al. 2019). Science will play a critical role in striving to objectively assess these risks, but communication and public discourse continue to be a key challenge.

Achieving a predator free 2050 is a complex task that will require new tools in pest management and innovative approaches that embody mātauranga Māori safely. This paper has exercised views from Western science and te ao Māori to demonstrate correlating interests that broaden the conventional discourse on complex matters. Reviewing participant views regarding the potential use of RNAi and gene drives in pest management, alongside the techno-scientific feasibility of each tool imparts depth and meaning to the ongoing work towards a predator-free 2050. Embodying our bicultural underpinning in Aotearoa New Zealand, upholding the Tiriti relationship, is critical to guiding a fair and equitable decision-making dialogue. Research should continue to test new approaches that advance meaningful collaboration with Māori researchers and novel ways of approaching complex goals.

\section{Notes}

1. In the Māori text, 'te tino rangatiratanga o o ratou wenua o ratou kainga me o ratou taonga katoa' is essential to understand. Mutu (2010) translates rangatira to mean paramount authority over land, villages, and taonga. Whereas the English text of the Treaty states ' ... exclusive and undisturbed possession of their lands and estates, forests, fisheries and other properties' (Treaty of Waitangi 1840). The diverging versions of the Treaty establish a point of contention in defining taonga. Historically, the Māori text (Te Tiriti o Waitangi) has been ignored in preference for the poorly translated English text (Treaty of Waitangi). This has led to tensions between Mãori and succeeding governments since 1840, and the disregard for the Māori worldview of taonga.

2. The use of an asterisk denotes quotes sourced from the data repositories of a previous study (e.g. S1, S2, S3) that are previously unpublished, and therefore have no citation attributed.

\section{Acknowledgements}

The authors are grateful to the participants for sharing their views and valuable time with this project. The authors also extend their thanks and gratitude to the editor and reviewers for their thoughtful comments and feedback on this paper. 


\section{Disclosure statement}

No potential conflict of interest was reported by the author(s).

\section{Funding}

This work was funded by the Ministry of Business, Innovation and Employment (New Zealand's Biological Heritage National Science Challenge, C09X1501).

\section{ORCID}

Symon Palmer (D) http://orcid.org/0000-0001-6519-4385

Peter K. Dearden (1) http://orcid.org/0000-0001-7790-9675

Ocean R. Mercier (D) http://orcid.org/0000-0003-1296-9954

Phillip J. Lester (I) http://orcid.org/0000-0002-1801-5687

\section{References}

Antonelli A, Humphreys AM, Lee WG, Linder HP. 2011. Absence of mammals and the evolution of New Zealand grasses. Proceedings of the Royal Society B: Biological Sciences. 278(1706):695701.

Baker M. 2012. The Korowai Framework: assessing GE through tribal values. New Genetics and Society. 31(1):87-98.

Belcher S. 2021. He Kete Hauora Taiao: a bicultural ecological assessment framework [PhD thesis]. Victoria University of Wellington, New Zealand.

Benton R, Frame A, Meredith P, Te Mātāhauariki Institute. 2013. Te Mātāpunenga: a compendium of references to the concepts and institutions of Māori customary law. In: Benton R, Frame A, Meredith P, Te Mātāhauariki Research Institute, editors. Wellington: Victoria University Press.

Burne AR, Haywood J, Lester PJ. 2015. Density-dependent effects of an invasive wasp on the morphology of an endemic New Zealand ant. Biol Invasions. 17(1):327-335.

Campbell H. 2004. Organics ascendant: curious resistance to GM. In: Hindmarsh R, Lawrence G, editors. Recoding nature. Sydney (NSW): University of New South Wales Press; p. 41-52.

Collier-Robinson L, Rayne A, Rupene M, Thoms C, Steeves T. 2019. Embedding indigenous principles in genomic research of culturally significant species: a conservation genomics case study. New Zealand Journal of Ecology. 43(3):1-9.

Dearden PK, Dearden PK, Gemmell NJ, Mercier OR, Lester PJ, Scott MJ, Buckley TR, Jacobs JME, Goldson SG, Penman DR. 2018. The potential for the use of gene drives for pest control in New Zealand: a perspective. Journal of the Royal Society of New Zealand. 48:225-244.

Dryzek JS, Nicol D, Niemeyer S, Pemberton S, Curato N, Bächtiger A, Batterham P, Bedsted B, Burall S, Burgess M, et al. 2020. Global citizen deliberation on genome editing. Science. 369 (6510):1435.

Edwards E, Toft R, Joice N, Westbrooke I. 2017. The efficacy of Vespex ${ }^{\oplus}$ wasp bait to control Vespula species (Hymenoptera: Vespidae) in New Zealand. International Journal of Pest Management. 63:65-76.

Edwards P, Fleming A, Lacey J, Lester L, Pinkard E, Ruckstuhl K, Bezuidenhout C, Payn T, Bayne K, Williams T. 2019. Trust, engagement, information and social licence - insights from New Zealand. Environmental Research Letters. 14(2):024010.

Esvelt KM, Gemmell NJ. 2017. Conservation demands safe gene drive. Public library of Science. PLoS Biology. 15:e2003850.

Esvelt KM, Smidler AL, Catteruccia F, Church GM. 2014. Concerning RNA-guided gene drives for the alteration of wild populations. eLife. 3:1-21. 
Everett-Hincks JM, Henaghan RM. 2019. Gene editing pests and primary industries - legal considerations. New Zealand Science Review. 75(2-3):31-36.

Feliú-Mójer MI. 2020. Gene editing communication must center marginalized communities. Environmental Communication. 14(7):877-880.

Fox K. 2020. The illusion of inclusion - the "All of Us" research program and indigenous peoples' DNA. New England Journal of Medicine. 383(5):411-413.

Garrison NA, Carroll SR, Hudson M. 2020. Entwined processes: rescripting consent and strengthening governance in genomics research with indigenous communities. The Journal of Law, Medicine \& Ethics. 48(1):218-220.

George DR, Kuiken T, Delborne JA. 2019. Articulating 'free, prior and informed consent' (FPIC) for engineered gene drives. Proceedings of the Royal Society B: Biological Sciences. 286 (1917):20191484.

Goldson SL, Bourdot GW, Brockerhoff EG, Byrom AE, Clout MN, McGlone MS, Nelson WA, Popay AJ, Suckling DM, Templeton MD. 2015. New Zealand pest management: current and future challenges. Journal of the Royal Society of New Zealand. 45:31-58.

Green W, Rohan M. 2012. Opposition to aerial 1080 poisoning for control of invasive mammals in New Zealand: risk perceptions and agency responses. Journal of the Royal Society of New Zealand. 42(3):185-213.

Harris RJ. 1991. Diet of the wasps Vespula vulgaris and V. germanica in honeydew beech forest of the South Island, New Zealand. New Zealand Journal of Zoology. 18:159-169.

Harrop TWR, Guhlin J, McLaughlin GM, Permina E, Stockwell P, Gilligan J, Le Lec MF, Gruber MAM, Quinn O, Lovegrove M, et al. 2020. High-quality assemblies for three invasive social wasps from the Vespula genus. G3-Genes Genomes Genetics. 10(10):3479-3488.

Hazardous Substances and New Organisms Act (HSNO). 1996. New Zealand legislation. [accessed 2021 October 7]. https://www.legislation.govt.nz/act/public/1996/0030/latest/DLM381222. html.

Heinemann JA. 2019. Should dsRNA treatments applied in outdoor environments be regulated? Environ International. 132:104856.

Hudson M, Mead ATP, Chagné D, Roskruge N, Morrison S, Wilcox PL, Allan AC. 2019. Indigenous perspectives and gene editing in Aotearoa New Zealand [Original Research]. Frontiers in Bioengineering and Biotechnology. 7:70.

Hudson M, Russell K, Uerata L, Milne M, Wilcox P, Port RV, Smith B, Toki V, Beaton A. 2016. Te Mata Ira-Faces of the Gene: developing a cultural foundation for biobanking and genomic research involving Māori. AlterNative: An International Journal of Indigenous Peoples. 12 (4):341-355.

Hutchings J, Reynolds P. 2004. The obfuscation of Tikanga Maori in the GM debate. [accessed 2021 Jun 11]. http://www.rangahau.co.nz/assets/hutching_renolds/GE_hutchings_reynolds.pdf.

Huvenne H, Smagghe G. 2010. Mechanisms of dsRNA uptake in insects and potential of RNAi for pest control: a review. Journal of Insect Physiology. 56:227-235.

Inwood SN, McLaughlin GM, Buckley TR, Cox MP, Handley KM, Steeves TE, Strabala TJ, McDougal R, Dearden PK. 2020. Opportunities for modern genetic technologies to maintain and enhance Aotearoa New Zealand's bioheritage. New Zealand Journal of Ecology. 44(2):3413.

Jones C. 2016. New treaty, new tradition. Wellington: Victoria University Press.

King-Hunt A. 2019. Novel biotechnological controls for social wasp eradication: exploring religious and spiritual Māori perceptions using an integrated Kaupapa Māori-centred Q methodology [unpublished M.A. thesis]. Victoria University of Wellington, New Zealand.

Kirk N, Kannemeyer R, Greenaway A, MacDonald E, Stronge D. 2019. Understanding attitudes on new technologies to manage invasive species. Pacific Conservation Biology. 26:35-44.

Lester PJ, Beggs JR. 2019. Invasion success and management strategies for social Vespula wasps. Annual Review of Entomology. 64:51-71.

Lester PJ, Brown SDJ, Edwards ED, Holwell GI, Pawson SM, Ward DF, Watts CH. 2014. Critical issues facing New Zealand entomology. New Zealand Entomologist. 37(1):1-13. 
Lester PJ, Bulgarella M, Baty JW, Dearden PK, Guhlin J, Kean JM. 2020. The potential for a CRISPR gene drive to eradicate or suppress globally invasive social wasps. Scientific Reports. 10(1):12398.

Lester PJ, Haywood J, Archer ME, Shortall CR. 2017. The long-term population dynamics of common wasps in their native and invaded range. Journal of Animal Ecology. 86(2):337-347.

Li M, Au LYC, Douglah D, Chong A, White BJ, Ferree PM, Akbari OS. 2017. Generation of heritable germline mutations in the jewel wasp Nasonia vitripennis using CRISPR/Cas9. Springer US. Scientific Reports. 7:901.

Lim ZX, Robinson KE, Jain RG, Chandra GS, Asokan R, Asgari S, Mitter N. 2016. Diet-delivered RNAi in Helicoverpa armigera - progresses and challenges. Journal of Insect Physiology. 85:8693.

Lu H-L, Vinson SB, Pietrantonio PV. 2009. Oocyte membrane localization of vitellogenin receptor coincides with queen flying age, and receptor silencing by RNAi disrupts egg formation in fire ant virgin queens. The FEBS Journal. 276:3110-3123.

MacDonald EA, Balanovic J, Edwards ED, Abrahamse W, Frame B, Greenaway A, Kannemeyer R, Kirk N, Medvecky F, Milfont TL, et al. 2020. Public opinion towards gene drive as a pest control approach for biodiversity conservation and the association of underlying worldviews. Environmental Communication. 14(7):904-918.

MacIntyre P, Hellstrom J. 2015. An evaluation of the costs of pest wasps (Vespula species) in New Zealand. [accessed 2021 May 11]. http://www.doc.govt.nz/Documents/conservation/threatsand-impacts/animal-pests/evaluation-pest-wasps-nz.pdf.

Mahuika N, Mahuika R. 2020. Wānanga as a research methodology. AlterNative: An International Journal of Indigenous Peoples. 16(4):369-377.

Majidiani S, PourAbad RF, Laudani F, Campolo O, Zappalà L, Rahmani S, Mohammadi SA, Palmeri V. 2019. RNAi in Tuta absoluta management: effects of injection and root delivery of dsRNAs. Journal of Pest Science. 92(4):1409-1419.

Mao Y-B, Cai W-J, Wang J-W, Hong G-J, Tao X-Y, Wang L-J, Huang Y-P, Chen X-Y. 2007. Silencing a cotton bollworm P450 monooxygenase gene by plant-mediated RNAi impairs larval tolerance of gossypol. Nature Publishing Group. Nature Biotechnology. 25:1307-1313.

Masucci JD. 2020. Developing double-stranded RNA as a new Varroa control product. American Bee Journal. June 2020:685-694.

McGlone M, Richardson S, Jordan G. 2010. Comparative biogeography of New Zealand trees: species richness, height, leaf traits and range sizes. New Zealand Journal of Ecology. 34 (1):137-151.

McLaughlin GM, Dearden PK. 2019. Invasive insects: management methods explored. Journal of Insect Science. 19(5):1-9.

Mead HM. 2003. Tikanga Maori: living by Maori values. Wellington (NZ): Huia.

Medin DL, Bang M. 2014. Who's asking?: native science, western science, and science education. Cambridge (MA): MIT Press.

Mercier OR, King Hunt A, Lester P. 2019. Novel biotechnologies for eradicating wasps: seeking Māori studies students' perspectives with Q method. Kōtuitui: New Zealand Journal of Social Sciences Online. 14(1):136-156.

Mikaere A. 2005. The Treaty of Waitangi and the recognition of Tikanga Māori. In: Belgrave M., Kawharu M, Williams D, editors. Waitangi revisited: perspectives on the treaty of Waitangi. Auckland: University of Otago; p. 330-348.

Mitter N, Worrall EA, Robinson KE, Li P, Jain RG, Taochy C, Fletcher SJ, Carroll BJ, Lu GQ, Xu ZP. 2017. Clay nanosheets for topical delivery of RNAi for sustained protection against plant viruses. Nature Plants. 3(2):16207.

Moffat K, Zhang A. 2014. The paths to social licence to operate: An integrative model explaining community acceptance of mining. Resources Policy. 39:61-70.

Montenegro De Wit M. 2020. Democratizing CRISPR? Stories, practices, and politics of science and governance on the agricultural gene editing frontier. Elementa Science of the Anthropocene. 8:9. 
Moro D, Byrne M, Kennedy M, Campbell S, Lester PJ. 2018. Identifying knowledge gaps for gene drive research to control invasive animal species: the next CRISPR step. Global Ecology and Conservation. 13:e00363.

Murphy EC, Russell JC, Broome KG, Ryan GJ, Dowding JE. 2019. Conserving New Zealand's native fauna: a review of tools being developed for the Predator Free 2050 programme. Journal of Ornithology. 160(3):883-892.

Mutu M. 2010. Constitutional intentions: the treaty of Waitangi texts. In: Tawhai MMV, editor. Weeping waters: the treaty of Waitangi and constitutional change. Wellington: Huia; p. 16-33.

National Academy of Medicine, National Academy of Sciences, and the Royal Society. 2020. Heritable human genome editing. Washington: The National Academies Press.

Noble C, Adlam B, Church GM, Esvelt KM, Nowak MA. 2018. Current CRISPR gene drive systems are likely to be highly invasive in wild populations. Cold Spring Harbor laboratory. eLIFE. 7:e33423.

Norton DA, Young LM, Byrom AE, Clarkson BD, Lyver PO, McGlone MS, Waipara NW. 2016. How do we restore New Zealand's biological heritage by 2050? Ecological Management \& Restoration. 17:170-179.

Ogilvie S. 2010. There's a rumble in the jungle - 1080 poisoning our forests or a necessary tool? In: Shelby R, Moore P, Mulholland M, editors. Māori and the environment: Kaitiaki. Wellington (NZ): Huia; p. 251-261.

Ogilvie S, McCarthy A, Allen W, Grant A, Mark-Shadbolt M, Pawson S, Richardson B, Strand T, Langer ER, Marzano M. 2019. Unmanned aerial vehicles and biosecurity: enabling participatory-design to help address social licence to operate issues. Forests. 10(8):695.

Palli SR. 2014. RNA interference in Colorado potato beetle: steps toward development of dsRNA as a commercial insecticide. Current Opinion in Insect Science. 6:1-8.

Palmer S. 2019. Māori businesses and the potential use of biotechnologies in pest wasp management. M.A. Thesis, Victoria University of Wellington, New Zealand.

Palmer S, Mercier OR. 2020. Biotechnologies in pest wasp control: taking the sting out of pest management for Mãori businesses? New Genetics and Society. 40(2):155-177.

Palmer S, Mercier OR, King-Hunt A. 2020. Towards rangatiratanga in pest management? Māori perspectives and frameworks on novel biotechnologies in conservation. Pacific Conservation Biology.

Powell M, Pyati P, Cao M, Bell H, Gatehouse JA, Fitches E. 2017. Insecticidal effects of dsRNA targeting the Diap1 gene in dipteran pests. Springer US. Scientific Reports. 7:15147.

Raghu S. 2015. Opinion: Is CRISPR-based gene drive a biocontrol silver bullet or global conservation threat? Proceedings of the National Academy of Sciences of the United States of America. 112:10565-10567.

Ratuva S. 2009. Commodifying cultural knowledge: corporatised western science and Pacific indigenous knowledge. International Social Science Journal. 60(195):153-163.

Revuelta L, Piulachs MD, Bellés X, Castañera P, Ortego F, Díaz-Ruíz JR, Hernández-Crespo P, Tenllado F. 2009. RNAi of ace1 and ace2 in Blattella germanica reveals their differential contribution to acetylcholinesterase activity and sensitivity to insecticides. Insect Biochemistry and Molecular Biology. 39:913-919.

Rogers-Hayden T, Hindmarsh R. 2002. Modernity contextualises New Zealand's Royal Commission on genetic modification: a discourse analysis. The Journal of New Zealand Studies. 1:41-61.

Royal Commission on Genetic Modification. 2001. Report of the Royal Commission on Genetic Modification. Chairman: Thomas Eichelbaum. Wellington (NZ): New Zealand Government Printer.

Royal Society Te Apārangi. 2019. Gene Editing: legal and regulatory implications. [accessed 2021 Apr 20]. https://www.royalsociety.org.nz/assets/Uploads/Gene-Editing-Legal-and-regulatoryimplications-DIGITAL.pdf.

Ruckstuhl K, Thompson-Fawcett M, Rae H. 2014. Māori and mining: Indigenous perspectives on reconceptualising and contextualising the social licence to operate. Impact Assessment and Project Appraisal. 32(4):304-314. 
Ruru J, Lyver PB, Scott N, Edmunds D. 2017. Reversing the decline in New Zealand's biodiversity: empowering Maori within reformed conservation law. Policy Quarterly. 13(2):65-71.

Russell JC. 2014. A comparison of attitudes towards introduced wildlife in New Zealand in 1994 and 2012. Journal of the Royal Society of New Zealand. 44(4):136-151.

San Miguel K, Scott JG. 2016. The next generation of insecticides: dsRNA is stable as a foliarapplied insecticide. Pest Management Science. 72:801-809.

Satterfield T, Roberts M. 2008. Incommensurate risks and the regulator's dilemma: considering culture in the governance of genetically modified organisms. New Genetics and Society. 27 (3):201-216.

Shaffer L. 2020. Inner workings: RNA-based pesticides aim to get around resistance problems. Proceedings of the National Academy of Sciences. 117(52):32823-32826.

Sissons J. 2019. Letters to a Maori prophet: living with Atua in mid-nineteenth-century Taranaki. Journal of the Polynesian Society. 128(3):261-277.

Smith C. 2006. Na Takoto Ana a Papatuanuku: the state of biotechnologies and Māori. In: Mulholland M, editor. State of the Māori Nation: twenty-first-century issues in Aotearoa. Auckland: Reed; p. 199--209.

Smith L, Pihama L, Cameron N, Mataki T, Morgan H, Te Nana R. 2019. Thought space Wānanga - a Kaupapa Māori decolonizing approach to research translation. Genealogy. 3(4):74.

Smith LT. 2012. Decolonizing methodologies, 2nd ed. Dunedin: Otago University Press.

Spradbery JP. 1973. Wasps: an account of the biology and natural history of social and solitary wasps, with particular reference to those of the British Isles. Canberra: Division of Entomology, Commonwealth Scientific and Industrial Research Organization.

Taitingfong RI. 2019. Islands as laboratories: Indigenous knowledge and gene drives in the pacific. Human Biology. 91(3):179-188.

Takeshita C. 2001. Bioprospecting and its discontents: indigenous resistances as legitimate politics. Alternatives. 26(3):259-282.

Tariq K, Ali A, Davies TGE, Naz L, Sohail S, Hou M, Ullah F. 2019. RNA interference-mediated knockdown of voltage-gated sodium channel $\left(M p N a_{v}\right)$ gene causes mortality in peach-potato aphid, Myzus persicae. Scientific Reports. 9:5291.

Taupo K. 2012. Negotiating the interface of genetic testing, biobanking and Māori ontology and epistemology. New Genetics and Society. 31(1):25-40.

Tsosie KS, Begay RL, Fox K, Garrison NA. 2020. Generations of genomes: advances in paleogenomics technology and engagement for Indigenous people of the Americas. Current Opinion in Genetics \& Development. 62:91-96.

Waitangi Tribunal. 2011. Ko Aotearoa Tenei - Te Taumata Tuatahi. [accessed 2020 Oct 10]. https://forms.justice.govt.nz/search/Documents/WT/wt_DOC_68356054/

KoAotearoaTeneiTT1W.pdf.

Weiner SA, Geffre AG, Toth AL. 2018. Functional genomics in the wild: a case study with paper wasps shows challenges and prospects for RNA interference in ecological systems. Genome. 61 (4):266-272.

Whyard S, Singh AD, Wong S. 2009. Ingested double-stranded RNAs can act as species-specific insecticides. Elsevier Ltd. Insect Biochemistry and Molecular Biology. 39:824-832.

Zamore PD. 2001. RNA interference: listening to the sound of silence. Nature Publishing Group. Nature Ecology \& Evolution. 8:746-750.

Zentner GE, Wade MJ. 2017. The promise and peril of CRISPR gene drives. BioEssays. 39:1700109. 